\title{
Application in Lieu of Money Penalty to Corruption Actors Based on Act No. 31 of 1999 jo. Act No. 20 of 2001 on Combating Crime of Corruption
}

\author{
Joko Hermawan Sulistyo ${ }^{1}$ and Jawade Hafidz $^{2}$
}

Abstract. Corruption resulted in losses to the state, resulting in the combating creation also sought refund of the state financial losses. Imprisonment and fined, have not been able to restore the country's financial losses due to corruption, and have not been able to take money from the corruption of the perpetrators, so it needs an additional form of criminal punishment imposed for compensation. Compensation will be imposed by the judge, as much as possible the amount equal to the property magnified by of corruption. Convicts are given a grace period of one month already se-binding court decision to pay it off. If within this period has ended, then the prosecutor as an executor of the state may seize and auction off property of the accused. However, in criminal application for compensation, there are still obstacles, among which is the difficulty to trace the perpetrators of corruption money and annihilate, use / divert money of corruption in other forms. Efforts to do is to foreclosure and auction of property belonging to criminal and his heirs, ruling subsidiary imprisonment, as well as a civil lawsuit and financial administration.

Keywords: Crime; Money Substitutes; and Corruption.

\section{Introduction}

Corruption in Indonesia has penetrated into the entire line of people's lives, and even said to have entrenched in society. Widespread corruption, carried out systematically by the increasingly sophisticated modus operandi. Corruption is not only the state of financial harm, but corruption also have violated the rights of social and economic, that are classified as extraordinary crime. In Indonesia's own country, the number of cases of corruption, as well as the modus operandi of state losses continued to increase from year to year, and even more the officials involved. Corruption is an act or acts arbitrarily and in violation of the rules. Corruption is not only intended to take advantage of money, but more than that. ${ }^{3}$

According Munir Fuady was quoted as saying by Jawade Haafiz Arsyad that this corruption is one kind of white collar crime or evil tie. In contrast to conventional crimes involving perpetrators of street (street crime, blue collar crime, blue collar crime), against white collar crime, the parties involved are those who are eminent people in the society and are usually highly educated. Even the modus operandi for this white collar crime such as corruption often be done with a sophisticated ways, even intermingled with theories in science, such as accounting and statistics. Therefore, although there is a patgulipat game, on the surface as if the deed is actually

\footnotetext{
${ }^{1}$ Student of Master of Law, Universitas Islam Sultan Agung Semarang and Prosecutor Republic of Indonesia, e-mail: hermawan9390@gmail.com

${ }^{2}$ Faculty of Law, Universitas Islam Sultan Agung

3 Jawade Hafidz Arsyad and Dian Karisma, 2018, Sentralisasi Birokrasi Pengadaan Barang \& Jasa Pemerintah, Cetakan Pertama, Sinar Grafika, Jakarta, p. 123.
} 
a white collar crime and it looks like an ordinary legal action. Thus, if measured by the sophistication of the modus operandi, the views of a class of people who are involved, or seen from the amount of funds looted, act white collar crime is clearly a crime of high grade, which actually motivated by the principle of a misnomer, namely Greedy is Beautiful. $^{4}$

Corruption is obviously very dangerous to the nation because its effects are not only detrimental to the state finances but also inhibit state or government for the welfare of its people. People are also affected because the perpetrator's actions that seeks only to enrich himself, his family, and cronies.

In the field of public service is also very prone to corruption, even if it is done by making a small fee, but the amount that must be spent each to receive services from the government, making people very burdened. Illegal levies made by the regulators or the public service providers has hampered efforts of state governments to implement good governance and free from corruption, collusion and nepotism.

In accordance with the characteristics of white collar crime, which is difficult to track because usually the perpetrator is a person who has a high social status (official), has the intelligence, related to the job, which by its allowing perpetrators to hide the evidence. In addition, the losses caused by corruption are usually not easily and quickly be felt by the victim. Compare with theft, robbery or murder. ${ }^{5}$

As a result of corruption is the main disadvantage uangan all countries. It has become clear, the state money that was corrupted by the perpetrators of corruption is public money, which should be used for the benefit of the people, but only enjoyed by a handful of people following the corrupt family and cronies.

In order to eradicate corruption, as a last resort is the imposition of criminal sanctions for perpetrators of corruption. Capital punishment imposed by the judge in the form of imprisonment and criminal fines are still not able to restore the country's financial losses due to corruption. There are criminal compensation, but still in the form of additional punishment. Mentioned in Article 18 paragraph (1) letter b Act No. 31 Of 1999 jo. Act No. 20 of 2001 that: "Besides additional penalty referred to the Criminal Law, as an additional penalty is Compensation will be as much as the same amount with property derived from criminal acts of corruption".

Basically, corruption is a criminal offense facing property or wealth, in this case property or property belonging to the state, so the state suffered losses due to corruption. Therefore, the main thing in the eradication of corruption is to restore the corrupted state financial losses and take all the money to corruption of the culprit.

Imprisonment and a criminal fine imposed judges, have not been able to restore the country's financial losses due to corruption, and have not been able to take money from the corruption that has been obtained by the perpetrators, so it needs an additional form of criminal punishment as paid restitution. However, until now criminal Compensation will still be additional criminal. The public prosecutor is not obliged me-demanding and judges are not required to decide criminal penal payment for replacement of the perpetrators of corruption. Compensation will be expected to

\footnotetext{
4Jawade Hafidz Arsyad, 2013, Korupsi Dalam Perspektif HAN (Hukum Administrasi Negara), First Edition, Sinar Grafika, Jakarta, p. 1-2.

${ }^{5}$ Chaerudin, dkk., 2008, Strategi Pencegahan Tindak Pidana Korupsi, Refika Aditama Bandung, p. 5.
} 
restore the country's financial losses and take all the money to corruption of the perpetrators of corruption

From the above discussion, the authors formulate the problem of: How does the application of criminal restitution against the perpetrators of corruption under Act No. 31 of 1999 jo. Act No. 20 of 2001 ?

\section{Discussion}

In this case, Lopez and Scott expressed his views about the corruption mentioned that in a legal sense, corruption is behavior that favor self-interest at the expense of others, by government officials who directly violates the legal limits on such behavior, while according to norms of the government can be considered corruption if laws are violated or not in the business of these actions are despicable. ${ }^{6}$

In another sense, corruption is also seen as the behavior does not adhere to the principle, that is to say in decision-making in the economic field, whether carried out by individuals in the private sector as well as public officials deviate from the rules. ${ }^{7}$

Acts of corruption committed by government officials is very detrimental to the finances of the country. Finance is the lifeblood of the country in the development of a country and so determine the viability per for Economic, either now or in the future.

According to A. Djoko Sumaryanto that the state financial losses can occur in two stages, namely at the stage of the funds will go to the state treasury and at the stage of funding will come out of the state treasury. At this stage of the funds will go to the state treasury, losses can occur through tax conspiracy, conspiracy fines, indemnification state conspiracy and smuggling, while at the stage of funding will come out of the state treasury losses occur as a result of mark-ups, corruption, the implementation of activities that do not in accordance with the program, and others. Acts that could harm the country's economy is criminal violations of the regulations issued by the government in its sphere of competence. ${ }^{8}$

Corruption has occurred in all areas of governance, whether executive, legislative, and judicial, known widely bureaucratic corruption, the corruption of the people who are fingering me state institutional authority, whether executive, legislative and judicial. ${ }^{9}$

Corruption has become a crime deemed damaging the joints of society and the state. State losses caused by corruption had been categorized as harmful. Corruption in Indonesia is a national problem that is recurrent and "emergency" that has been faced by Indonesia from time to time in the relatively long timescales so special corruption

\footnotetext{
${ }^{6}$ IGM Nurdjana, 2010, Sistem Hukum Pidana dan Bahaya Laten Korupsi ?Perspektif Tegaknya Keadilan Melawan Mafia Hukum, First Edition, Pustaka Pelajar, Yogyakarta, p. 16.

${ }^{7}$ Marwan Effendy, 2012, Sistem Peradilan Pidana, Tinjauan Terhadap Beberapa Per-kembangan Hukum Pidana, Second Edition, Referensi, Jakarta, p. 83.

${ }^{8}$ A. Djoko Sumaryanto, 2009, Pembalikan Beban Pembuktian Tindak Pidana Korupsi Dalam Rangka Pengembalian Kerugian Keuangan Negara, Prestasi Pustaka Publisher, Jakarta, p. 26-27.

${ }^{9}$ Amir Syamsuddin, 2008, Integritas Penegak Hukum, Hakim, Jaksa, Polisi, dan Pengacara, Kompas, Jakarta, p. 135.
} 
court is expected to help resolve a number of corruption crimes the past in order to recover property lost state. ${ }^{10}$

The problem of return losses to the state must be resolved, because essentially the completion of restitution countries me-rupakan mandated by law that must be implemented by each institution head of government or state officials, particularly as the implemen-tation of the function of the internal control system are attached to each leader or even the whole range of the state apparatus. ${ }^{11}$

Settlement compensation for countries that are the domain of criminal law, in principle, based on the positive law in Indonesia, namely the Criminal Code as the general law (lex generalis) and Act No. 31 of 1999 jo. Act No. 20 of 2001 on Corruption Eradication, as well as Act No. 30 of 2002 on the Corruption Eradication Commission (lex specialist).

Criminal threats in the provisions of Act No. 31 of 1999 jo. Act No. 20 of 2001 against the criminals are able to form of imprisonment and also fined. In an effort to obtain the maximum financial return in the country-the corruption by corrupt individuals, then in Act No. 31 of 1999 jo. Act No. 20 of 2001 also explores the concept of "efforts to recover losses to the state", ie in all contingencies Article 18 as one of the additional penalty. It is as stated in the provisions of Chapter V of the UNCAC 2003 on Asset Recovery has been ratified by Act No. 7 of 2006 on the Ratification of the United Nations Convention against Corruption, 2003 (United Nations Convention Against Corruption in 2003).

In the provisions of Act No. 31 of 1999 jo. Act No. 20 of 2001, one way to restore the country's lost due to corruption is to provide an additional form of punishment for compensation. This effort has produced results, in the form of revenue to the state treasury from the payment in lieu of some convict a predetermined amount of money payment successor.

In the annual report released by the Commission, there are three (3) factors that are relevant indicators of the deterrent effect of corruption, which included the maximum punishment in any case of corruption charges, which included additional penalty in the form of indemnification of state financial and impoverish the threat of criminals. The third indicator of this is being intensively carried out by the Commission in order to ensure a deterrent effect for corruptors. ${ }^{12}$

Criminal definition Compensation will be drawn from Article 18 paragraph (1) letter b of Act No. 31 of 1999, the Compensation amount at most equal to the wealth gained from corruption. To be able to determine and prove the actual number of property derived convicted of corruption, not just property that is still controlled by the convict at the time of the fall of the court ruling, but also treasures the result of corruption at the time of the reading of the verdict has been transferred the accused to others ${ }^{13}$

\footnotetext{
${ }^{10}$ Efi Laila Kholis, 2010, Pembayaran Uang Pengganti Dalam Perkara Korupsi, First Edition, Solusi Publishing, Depok,p. 5.

${ }^{11}$ A.Y. Suryanajaya, 2008, Kerugian Negara Dalam Perspektif Hukum Administrasi Publik, Masalah dan Penyelesaian, Eko Jaya, Jakarta, p. 1.

${ }^{12}$ Husin Wattimena, 2017, Penerapan Ancaman Sanksi Pidana Tambahan Bagi Pengembalian Kerugian Keuangan Negara Dalam Tindak Pidana Korupsi, First Edition, Deepublish, Yogyakarta, p. 104.

${ }^{13}$ Efi Laila Kholis, op.cit., p. 15.
} 
Article 18 of Act No. 31 of 1999 jo. Act No. 20 of 2001 regulating the type of additional penalty which may threatened to defendants who violate the clauses provided for in Article 17, namely Article 2, Article 3, Article 5 and Article 14 of Act No. 31 of 1999 jo. Act No. 20 of 2001. Criminal additional wearable that additional criminal contained Article 10 of the Criminal Code, namely the lifting of certain rights, deprivation of certain goods, and the announcement of the verdict. Besides additional penalty as everywhere in the Penal Code, there are additional criminal who arranged separately for the corrupt, namely: ${ }^{14}$

- Confiscation of movable tangible or intangible or immovable goods used for, or act of corruption, including the convict's corporation where corruption took place, as well as of goods replacing such items;

- Compensation will be as much as the same amount with property derived from criminal acts of corruption;

- The closure of all or part of the company for a maximum of 1 year;

- Withdrawal of all or part of certain rights or removal of all or part of particular benefit that has been or may be granted by the government to convict.

In the case of a judge convict an additional form of compensation, the convict was given a grace period of one month after the court decision is legally binding for payment. If within this period has ended, then the prosecutor as an executor of the state may seize and auction off property of the accused [Article 18 paragraph (2) of Act No. 31 Of 1999 jo. Act No. 20 of 2001].

In practice, criminal decisions for compensation were variations amount that can be caused by several factors, among others, as the judges have their own calculation, partly the result of corruption is in-rollback or corruption committed by more than one person so that criminal Compensation will be charged together -same. ${ }^{15}$

Arrangements regarding the criminal restitution in Article 18 of Act No. 31 of 1999 jo. Act No. 20 of 2001 was minimal, resulting in the emergence of various problems. One is to determine how many criminal restitution money that can be charged to the defendant. Article 18 paragraph (1) letter b Act No. 31 Of 1999 jo. Act No. 20 of 2001 just decided simple formula regarding the amount of money substitutes, as much as possible together with the wealth gained from corruption, it can be interpreted in the amount of money substitutes can be calculated based on the value of the property of the accused derived from corruption offenses indicted. Then to determine the amount of money substitutes, first of all judges must carefully sort out which parts of a whole treasure defendant derived from corruption against her and which ones are not. After sorting, the judge and then be calculating how the amount of restitution to be charged. In practice, with this concept the judge would have difficulty in determining the amount of restitution. It caused: ${ }^{16}$

- Judges will be difficult to sort out which assets derived from corruption and which are not, because of the complexity of its development of an offense of corruption is increasing. Moreover, to do this obviously needs special expertise and data and complete information. Not to mention when it comes to the time which is certainly

\footnotetext{
${ }^{14}$ Ibid.,p. 11-12.

${ }^{15}$ Ibid., p. 15.

${ }^{16}$ Ibid.,p. 18- 19.
} 
not for a while, especially if the property is to be calculated are abroad and thus require diplomatic bureaucracy that must be very complicated and time consuming;

- Calculated the amount of money a replacement will be difficult to do if the defendant is to be assessed assets turned out to have been converted in the form of asset-based nature has fluctuating value, that value continues to change.

Obstacles in the imposition of Compensation in the framework of the financial settlement have been revealed by Ramelan, among other things: ${ }^{17}$

- Cases of corruption may be disclosed after walking in over a long time, making it difficult to trace the money or proceeds acquired wealth from corruption;

- With corruption efforts have to spend money from corruption or use / switch in other forms, including on behalf of another person's name that is difficult to reach the law;

- In the criminal restitution payments, the convict many who can not afford;

- The presence of a third party who is suing the government over seized evidence in order to fulfill the payment of money substitutes.

Implementation of the state financial losses due to the return of corruption is also not necessarily be able to just do. In addition to waiting for the payment of money in lieu of the convicted of corruption cases which require a long time, refund a replacement to the state treasury can not be directly carried out, because there must be a bureaucratic procedure passed, so it takes time to indemnification financial state to state coffers in order to soon be used for public welfare. ${ }^{18}$

Indemnification of the state of corruption through money substitutes is one of the important effort in the eradication of corruption. The return is not easy because corruption is an extraordinary crimes that the perpetrators came from intellectuals and has an important position. In Act No. 31 of 1999 jo. Act No. 20 of 2001, has set up three (3) attempts to do in the settlement of arrears of money substitutes, namely: ${ }^{19}$

- Foreclosure and auction of property belonging to the convicted person and heirs after a court decision has permanent legal force;

- Verdict subsidiary imprisonment; and

- Civil lawsuit and financial administration.

\section{Closing}

\subsection{Conclusion}

Acts of corruption committed by government officials is very detrimental to the finances of the country. Indemnification of state financial problems must be resolved, because essentially the completion of state compensation is mandated by law that must be implemented. Settlement compensation for countries that are the domain of criminal law in a corruption case based Act No. 31 Of 1999 jo. Act No. 20 of 2001.

In an effort for maximum gain-healers development state finances corrupted by the criminals, then in Act No. 31 of 1999 jo. Act No. 20 of 2001 also explores the concept of

\footnotetext{
${ }^{17}$ Ibid., p. 15- 16.

${ }^{18}$ Husin Wattimena, op.cit., p. 9.

${ }^{19}$ Ibid., p. 83.
} 
"efforts to recover losses to the state, namely the provisions of Article 18 as a form of additional punishment for compensation. In the case of a judge convict an additional form of compensation, the convict was given a grace period of one month after the court decision is legally binding for payment. If within this period has ended, then the prosecutor as an executor of the state may seize and auction off property of the accused.

The obstacles in the imposition of the payment of a substitute in the settlement of state finance, among other things: (1) the lawyer-expression cases walking in over a long time, making it difficult to trace the money or the results of the wealth derived from corruption, (2) corruption has spend money from corruption or use / switch in other forms, including on behalf of another person's name that is difficult to reach the law, (3) the convict many who can not pay, and (4) any third party who is suing the government over seized evidence in order fulfillment of paid restitution. Efforts need to be made in the settlement of arrears of money substitutes, namely: (1) the confiscation and auction of property belonging to the convicted person and heirs after a court ruling backs possess binding legal force,

\subsection{Suggestion}

Keep in search efforts wealth and forceful measures at the stage of investigation in the case to ask for information about the entire assets of the suspect, his wife and his children, so that can know all of the assets property of the convict in the trial court, and sentenced to no longer be able to evade to pay compensation by reason of having no possessions again.

\section{Bibliography}

[1] Djoko Sumaryanto, 2009, Pembalikan Beban Pembuktian Tindak Pidana Korupsi Dalam Rangka Pengembalian Kerugian Keuangan Negara, Prestasi Pustaka Publisher, Jakarta.

[2] A.Y. Suryanajaya, 2008, Kerugian Negara Dalam Perspektif Hukum Administrasi Publik, Masalah dan Penyelesaian, Eko Jaya, Jakarta.

[3] Amir Syamsuddin, 2008, Integritas Penegak Hukum, Hakim, Jaksa, Polisi, dan Pengacara, Kompas, Jakarta.

[4] Chaerudin, dkk., 2008, Strategi Pencegahan Tindak Pidana Korupsi, Refika Aditama Bandung.

[5] Efi Laila Kholis, 2010, Pembayaran Uang Pengganti Dalam Perkara Korupsi, First Edition, Solusi Publishing, Depok.

[6] Husin Wattimena, 2017, Penerapan Ancaman Sanksi Pidana Tambahan Bagi Pengembalian Kerugian Keuangan Negara Dalam Tindak Pidana Korupsi, First Edition, Deepublish, Yogyakarta.

[7] IGM Nurdjana, 2010, Sistem Hukum Pidana dan Bahaya Laten Korupsi ?Perspektif Tegaknya Keadilan Melawan Mafia Hukum?, First Edition, Pustaka Pelajar, Yogyakarta.

[8] Jawade Hafidz Arsyad dan Dian Karisma, 2018, Sentralisasi Birokrasi Pengadaan Barang \& Jasa Pemerintah, First Edition, Sinar Grafika, Jakarta. 
[9] ----------, 2013, Korupsi Dalam Perspektif HAN (Hukum Administrasi Negara), First Edition, Sinar Grafika, Jakarta.

[10] Marwan Effendy, 2012, Sistem Peradilan Pidana, Tinjauan Terhadap Beberapa Perkembangan Hukum Pidana, Second Edition, Referensi, Jakarta. 